\title{
STRUKTUR KOMUNITAS MAKROZOOBENTHOS DI KAWASAN EKOSISTEM PESISIR PULAU SEPANJANG KABUPATEN SUMENEP
}

\author{
Ahmad Faris Suparno (1), Insafitri (2), Agus Romadhon (2) \\ ${ }^{1}$ Mahasiswa Jurusan IImu Kelautan, Universitas Trunojoyo Madura \\ ${ }^{2}$ Dosen Jurusan IImu Kelautan, Universitas Trunojoyo Madura \\ JI.Raya Telang No 02 Kamal Bangkalan Madura 69162
}

'MarineFaris9@gmail.com

\begin{abstract}
ABSTRAK
Makrozoobenthos merupakan suatau organisme dasar perairan yang hidup di permukaan (Epifauna) atau didalam (infauna) substrat dasar ekositem pesisir yang berupa ekositem mangrove dan lamun. Makrozoobentos merupakan salah satu indikator kesehatan lingkungan akuatik yang baik Penelitian ini dilakukan pada bulan Mei-Juni 2017 yang berlokasi di Pulau Sepanjang Kabupaten Sumenep yang bertujuan untuk 1. Mengetahui parameter kualitas perairan yang berada pada setiap lokasi penelitian 2. Mengetahui jenis makrozoobenthos di setiap stasiun penelitian yang berada pada kawasan pesisir ekosistem pulau sepanjang 3. Mengetahui perbedaan komposisi makrozoobenthos di setiap stasiun penelitian yang berada pada kawasan pesisir ekosistem pulau sepanjang 4. Mengetahui struktur komunitas makrozoobenthos yang terdapat pada kawasan pesisir di perairan Pulau Sepanjang Kabupaten Sumenep.Pengambilan data dilakukan pada ekositem mangrove dan lamun, dengan metode purposive sampling. Berdasrkan hasil pengamatan ditemukan 21 jenis dari 3 filum. Dari hasil perhitungan struktur komunitas Stasiun 1 mendapatkan nilai indeks keanekaragaman yang rendah indeks keseragaman sedang dan indeks dominasi sedang yang menandakan indikasi adanya tekanan yang berat dan ekosistem tidak stabil, penyebaran spesies rendah dan kestabilan komunitas rendah dan terjadinya dominasi suatu spesies yang tinggi.Stasiun 2 dan 3 memiliki nilai keanekaragaman sedang indeks keseragaman tinggi dan indeks dominasi rendah yang menandakan produktivitas lingkungan cukup, kondisi ekosistem cukup seimbang, tekanan ekologis sedang penyebaran tiap spesies sedang dan kestabilan komunitas sedang sehingga tidak terjadinya dominasi dari suatu spesies.
\end{abstract}

Kata Kunci : Struktur Komunitas, Makrozoobenthos,Pulau Sepanjang

\section{PENDAHULUAN}

Kawasan pulau kecil merupakan kawasan dengan sumberdaya alam yang produktif. Sumberdaya alam yang dapat ditemui berupa kekayaan ekosistem, seperti ekosistem mangrove, lamun terumbu karang beserta biota yang berasosiasi pada ekosistem tersebut (Dahuri 2003). Mangrove dan lamun merupakan ekosistem yang ada pada pulau-pulau kecil yang memiliki keanekaragaman biota dan makluk hidup sebagai penyusun ekosistem tersebut. Bagian dasar atau substrat dihuni oleh berbagai macam organisme, salah satunya adalah benthos. Makrozoobentos berperan dalam proses penguraian bahan organik terutama dalam biodegradasi sisa tanaman dan logam berat pencemar lingkungan (Setiawan 2010). Makrozoobentos merupakan salah satu indikator kesehatan lingkungan akuatik yang baik (Chessman 1995). Makrozoobentos memiliki sifat 
kepekaan terhadap beberapa bahan pencemar, mobilitas yang rendah, mudah ditangkap serta memiliki kelangsungan hidup yang panjang. Oleh karena itu peran makrozoobentos dalam keseimbangan suatu ekosistem perairan dapat menjadi indikator kondisi ekologi terkini pada suatu kawasan tertentu (Pong-Masak dan Rzan 2006). Berdasarkan penjabaran perlu dilakukan penelitian yang bertujuan untuk menelaah struktur komunitas makrozoobentos serta hubungannya dengan keadan ekosistem pesisir dan beberapa parameter fisika dan kimi kualitas perairan yang memmpengaruhi kawasan ekosistem mangrove dan pesisir di Pulau Sepanjang kabupaten Sumenep.

Berdasarkan penelusuran Pulau Sepanjang yang merupakan salah satu pulau kecil dan yang memiliki ekosistem daerah pesisir yang cukup kompleks. Sehingga perlu dilakukan penelitian untuk mengetahui (1) jenis dan komposisi makrozoobenthos; (2) struktur komunitas makrozoobenthos yang terdapat pada kawasan pesisir di perairan Pulau Sepanjang Kabupaten Sumenep agar nantinya dapat diketahu kondisi ekosistem yang ada di wilayah pesisir pulau sepanjang.

\section{METODE}

\section{a. Lokasi Penelitian}

Penelitian ini dilaksanakan pada bulan Februari-Maret 2017 di Pulau Sepanjang Kecamatan Sapeken yang secara administratif berada dalam wilayah Kabupaten Sumenep, Provinsi Jawa Timur. Pulau Sepanjang berada pada koordinat LS: 0706'07.1" dan BT: 115059'17.2". Pengambilan data dilakukan di 3 titik pengamatan yang terdapat ekosistem mangrove dan lamun dengan menggunakan metode purposive sampling. Pengambilan data kerapatan mangrove dan makrozoobenthos menggunakan transek kuadrat, transek mangrove menggunakan 10 $x 10 \mathrm{~m}^{2}$ dengan didalam nya terdapat 5 transek makrozoobenthos yang berukuran $1 \times 1 \mathrm{~m}^{2}$ dan digali pada substrat sedalam 30 $\mathrm{cm}$ (Bengen 2003). Pengambilan data kerapatan lamun dan data makrozoobenthos dilakukan dengan transek $1 \times 1 \mathrm{~m}^{2}$ dilakukan 3 ulangan sejajar garis pantai (Ruswahyuni 2008).

\section{b. Analisa Data}

- Kerapatan Mangrove

Data jumlah tegakan mangrove yang diperoleh kemudian dihitung tingkat

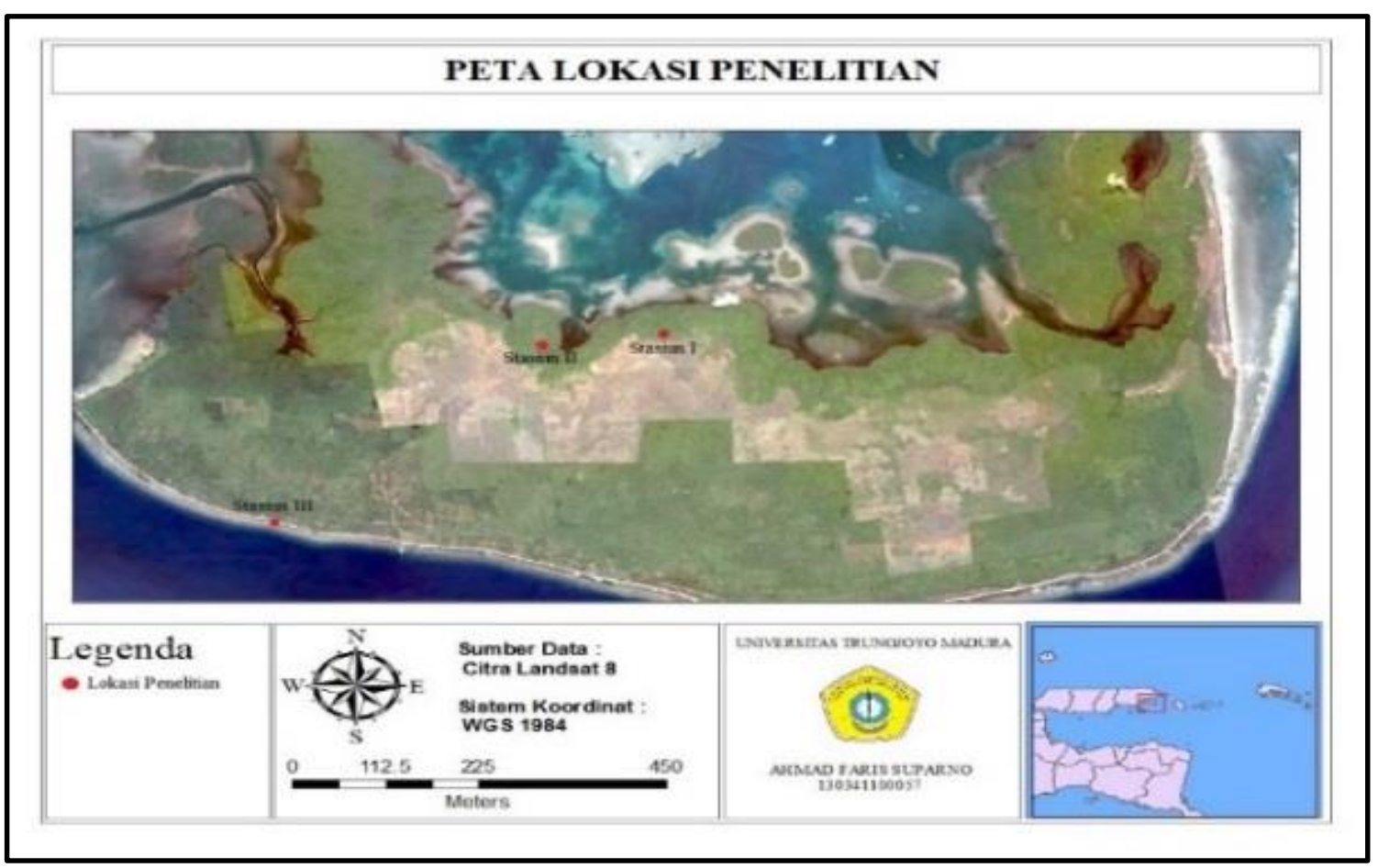

Gambar 1. Lokasi Penelitian Pulau Sepanjang 
kerapatannya berdasarkan rumus kerapatan mangrove (Bengen 2003):

Keterangan :

$$
\mathrm{Di}=\frac{n i}{A}
$$

$\mathrm{Di}=$ kerapatan jenis ke-i

$\mathrm{ni}=$ jumlah total individu ke-i

$\mathrm{A}=$ luas total area pengambilan

Hasil yang di peroleh kemudian di bandingkan dengan kriteria Kerapatan Mangrove menurut Keputusan Menteri Negara Lingkungan Hidup No. 201 tahun 2004 untuk menetukan kondisi ekosistem mangrove.

\section{-Kerapatan Lamun}

Kerapatan jenis merupakan perbandingan antara jumlah total individu dengan unit area yang diukur. Kerapatan jenis lamun dapat dihitung dengan persamaan .Sedangkan jumlah tegakan lamun dihtung kerapatannya berdasarkan rumus (Tuwo 2011) :

$$
\mathrm{KJi}=\frac{\mathrm{ni}}{\mathrm{A}}
$$

Keterangan :

$\mathrm{Kji}=$ Kerapatan jenis ke-i

$\mathrm{Ni}=$ Jumlah total individu

$A=$ Luas area total pengambilan

\section{- Struktur Komunitas Makrozoobenthos}

Indeks keanekaragaman merupakan suatu perhitungan yang digunakanan untuk mengetahui keanekaragaman jenis biota perairan termasuk makrozoobenthos. Indeks keanekaragaman (Shanon-Winer) yang digunakan sebagai berikut (Krebs 1989) :

$$
\boldsymbol{H}^{\prime}=-\sum_{i=1}^{s} p i \ln p i \quad \begin{aligned}
& \text { Keterangan : } \\
& \mathrm{H}=\text { Keanekaragaman } \\
& \mathrm{Pi}=\mathrm{n} / \mathrm{N} \\
& \mathrm{ni}=\text { Jumlah individu jenis } \mathrm{i} \\
& \mathrm{N}=\text { Jumlah individu } \\
& \mathrm{S}=\text { Jumlah Genus }
\end{aligned}
$$

Keseragaman dari makroozoobenthos merupakan proporsi dari masing-masing spesies makrozoobenthos yang hidup pada tempat tertentu. Indeks keseragaman (evenness) yang digunakan sebagai berikut (Bengen 2000). :

$$
E=\frac{H^{\prime}}{\ln S} \quad \begin{gathered}
\text { Keterangan : } \\
\text { E }=
\end{gathered} \text { Kemerataan }
$$

$$
\begin{aligned}
& \mathrm{H}^{\prime}= \\
& \text { Keanekaragaman } \\
& \mathrm{S}=\text { Jumlah Spesies }
\end{aligned}
$$

Untuk mengetahui adanya dominasi dari suatu jenis tertentu digunakan analisa indeks dominasi. indeks dominasi (simpson) yang digunakan sebagai berikut (Krebs 1989):

$$
\mathrm{C}=\sum_{\mathrm{i}=1}^{\mathrm{s}}\left(\frac{\mathrm{ni}}{\mathrm{N}}\right)^{2} \quad \begin{aligned}
& \text { Keterangan : } \\
& \mathrm{C}=\text { Indeks Dominansi } \\
& \mathrm{Ni}=\text { jumlah individu } \\
& \mathrm{N}=\text { jumlah total individu }
\end{aligned}
$$

\section{HASIL PEMBAHASAN}

Pulau Sepanjang merupakan pulau yang berada di Kabupaten Sumenep. Pulau Sepanjang merupakan salah satu pulau yang terbesar yang di gugusan kepulauan kangean dan termasuk kedalam wilayah Kecamatan Sapeken. Terdapat dua desa yang berda di Pulau Sepanjang yaitu Desa Sepanjang dan Desa Tanjung Kiaok. Pulau Sepanjang memiliki luasan $\pm 72,11 \mathrm{~km}^{2}$ dan luasan tersebut merupakan $34,73 \%$ dari wilayah Kecamatan Sapeken yang memiliki luas $204,77 \mathrm{~km}^{2}$.

\section{- Ekosistem Mangrove}

Pada Stasiun I untuk titik la yaitu berbatasan dengan daratan memiliki tegakan sebayak $14-11$ pohon $/ 100 \mathrm{~m}^{2}$, titik lb memiliki 
Tabel 1. Tegakan Mangrove Stasiun I

\begin{tabular}{cccc}
\hline Titik & Jenis & Pohon & Kerapatan * \\
\hline \multirow{3}{*}{ I a } & Rhizopora Apiculata & 0 & 0 \\
& Ceriops Tagal & 11 & 1.100 \\
Jumlah & Blugueira Cylindrica & 3 & 300 \\
I b & & 14 & 1.400 \\
& Rhizopora Apiculata & 0 & 0 \\
Jumlah & Ceriops Tagal & 10 & 1.000 \\
\hline \multirow{2}{*}{ I c } & Blugueira Cylindrica & 1 & 100 \\
& & 11 & 1.100 \\
Jumlah & Rhizopora Apiculata & 1 & 100 \\
& Ceriops Tagal & 12 & 1.200 \\
& Blugueira Cylindrica & 0 & 0 \\
& & 13 & 1.300 \\
\hline
\end{tabular}

Tabel 2. Tegakan Mangrove Stasiun II

\begin{tabular}{cccc}
\hline Titik & Jenis & Pohon & Kerapatan * \\
\hline \multirow{3}{*}{ II a } & Rhizopora Apiculata & 0 & 0 \\
& Ceriops Tagal & 16 & 1.600 \\
Jumlah & Blugueira Cylindrica & 0 & 0 \\
\hline \multirow{3}{*}{ II b } & Rhizopora Apiculata & 16 & 1.600 \\
& Ceriops Tagal & 1 & 100 \\
Jumlah & Blugueira Cylindrica & 0 & 1.500 \\
& & 16 & 0 \\
II C & Rhizopora Apiculata & 4 & 1.600 \\
& Ceriops Tagal & 11 & 400 \\
Jumlah & Blugueira Cylindrica & 0 & 1.100 \\
\hline
\end{tabular}

tegakan sebanyak 11 pohon $/ 100 \mathrm{~m}^{2}$, titik lc memiliki tegakan sebanyak 13-11 pohon $/ 100 \mathrm{~m}^{2}$. Hasil tersebut kemudian dikonversikan menjadi Pohon/Ha dan didapatkan hasil perhitungan tingkat kerapatan 1100-1400 pohon/ha. Berdasarkan kriteria tingkat kerapatan mangrove pada stasiun I berdasarkan Keputusan Menteri Negara Lingkungan Hidup No. 201 tahun 2004 termasuk dalam kriteria sedang. Stasiun II yang berada di Pajan Barat utuk substasiun II a memiliki tegakan sebanyak 16 pohon $/ 100 \mathrm{~m}^{2}$, substasiun II b memiliki tegakan sebanyak 16 pohon $/ 100 \mathrm{~m}^{2}$, dan substasiun III c memiliki tegakan sebanyak 15 pohon/100m². Hasil tersebut kemudian dikonversikan menjadi Pohon/Ha dan didapatkan hasil perhitungan tingkat kerapatan substasiun antara 15001600 pohon/ha dan termasuk dalam kategori kerapatan mangrove rapat.

\section{- Ekosistem Padang Lamun}

Padang lamun merupakan habitat yang bagus bagi biota-biota di sekelilingnya sebagai tempat berlindung dan makan.
Bahkan untuk beberapa jenis biota, padang lamun merupakan tempat memiijah (Kikuchi 1980 dalam Ruswahyuni 2008). Ekosistem lamun yang ditemukan pada lokasi penelitian ditemukan pada daerah dengan substrat pasir. Substrat pasir merupakan substrat yang sangat cocok bagi daerah hidupnya lamun. Perhitungan kerapatan lamun ini natinya akan di analisa dan di bandingkan dengan makrozoobenthos yang di temukan. Kerapatan lamun pada lokasi penelitian di setiap sub stasiunnya dapat dilihat pada Tabel 3, Tabel 4 dan Tabel 5.

Lamun yang ditemukan pada daerah pesisir pulau sepanjang memiliki jumlah kerapatan yang berbeda pada setiap sub stasiun yang terdapat pada tiga titik pengamatan. Pada sub stasiun Illa memiliki kerapatan perjenis berturut- turut sebesar 80$1220 \mathrm{ind} / \mathrm{m}^{2}$, pada substasiun IIlb memiliki tingkat kerapatan jenis sebesar 65-1120 ind/ $\mathrm{m}^{2}$, dan pada sub stasiun IIlc mimiliki tingkat kerapatan berkisar antara 135-1315 ind/ $\mathrm{m}^{2}$. 
Tabel 3. Kerapatan Lamun Sub Stasiun III-a

\begin{tabular}{|c|c|c|c|c|c|c|}
\hline \multirow{2}{*}{ Jenis } & \multicolumn{3}{|c|}{ III a } & \multirow{2}{*}{$\boldsymbol{\Sigma}$} & \multirow{2}{*}{ Kriteria (ind $/ \mathbf{m}^{2}$ ) } & \multirow{2}{*}{ Keterangan } \\
\hline & T1 & T 2 & T3 & & & \\
\hline Enhalus Acorides & 45 & 25 & 10 & 80 & $25-224$ & Jarang \\
\hline Syringodium isoetifolium & 70 & 130 & 120 & 320 & $225-424$ & Agak Rapat \\
\hline Thalassia hemprici & 260 & 410 & 550 & 1220 & $\geq 625$ & Sangat Rapat \\
\hline Jumlah Total & 375 & 565 & 680 & 1620 & & \\
\hline
\end{tabular}

Tabel 4. Kerapatan Lamun Sub Stasiun III-b

\begin{tabular}{|c|c|c|c|c|c|c|}
\hline \multirow{2}{*}{ Jenis } & \multicolumn{3}{|c|}{ III $\mathbf{b}$} & \multirow{2}{*}{$\boldsymbol{\Sigma}$} & \multirow{2}{*}{ Kriteria (ind/ $\mathbf{m}^{2}$ ) } & \multirow{2}{*}{ Keterangan } \\
\hline & T1 1 & T 2 & T 3 & & & \\
\hline Enhalus Acorides & 0 & 45 & 20 & 65 & $25-224$ & Jarang \\
\hline Syringodium isoetifolium & 105 & 40 & 35 & 180 & $25-224$ & Jarang \\
\hline Thalassia hemprici & 340 & 445 & 335 & 1120 & $\geq 625$ & Sangat Rapat \\
\hline Jumlah Total & 445 & 530 & 390 & 1365 & & \\
\hline
\end{tabular}

Tabel 4. Kerapatan Lamun Sub Stasiun III-c

\begin{tabular}{|c|c|c|c|c|c|c|}
\hline \multirow{2}{*}{ Jenis } & \multicolumn{3}{|c|}{ III c } & \multirow{2}{*}{$\boldsymbol{\Sigma}$} & \multirow{2}{*}{ Kriteria (ind $/ \mathrm{m}^{2}$ ) } & \multirow{2}{*}{ Keterangan } \\
\hline & T 1 & T2 & T 3 & & & \\
\hline Enhalus Acorides & 45 & 75 & 15 & 135 & $25-224$ & Jarang \\
\hline Syringodium isoetifolium & 115 & 95 & 85 & 292 & $225-424$ & Agak Rapat \\
\hline Thalassia hemprici & 450 & 425 & 440 & 1315 & $\geq 625$ & Sangat Rapat \\
\hline Jumlah Total & 610 & 595 & 540 & 1745 & & \\
\hline
\end{tabular}

Berdasarkan kerapatan lamun (BraunBlanquet 1965 dalam Haris dan Gosari 2012) dapat dinyatakan pada setiap substasiun penelitian memiliki nilai tingkat kerapatan 25-224 (ind $/ \mathrm{m}^{2}$ ) merupakan kerapatan dengan kriteria kerapatan jarang. Pengukuran kualitas perairan yang dilakukan bertujuan untuk menentukan kualitas perairan yang ada dilokasi penelitian. Parameter kualitas yang baik natinya akan menjadikan lokasi penelitian tersebut semakin baik. Sesuainya kondisi parameter kualitas perairan di lokasi penelitian akan mendukung kelangsungan hidup dari makrozoobenthos.

Hasil pengukuran nilai beberapa parameter kualitas air di beberapa sub stasiun menunjukkan terdapat ketidak sesuaian kualitas perairan berdasarkan Kepmen LH No 51 Tahun 2004. Akan tetapi tidak berpengaruh langsung terhadap makrozoobenthos yang ada karena kualitas perairan yang didapatkan masih dalam kadar normal bagi perairan dan masih sesuai bagi kehidupan makrozoobenthos yang di temukan. Kelimpahan dan keanekaragaman dari makrozoobenthos biasanya merupakan indikator adanya gangguan ekologi yang terjadi pada lingkungan tersebut (Setiawan, 2009).

Pengambilan data makrozoobenthos pada stasiun A didapatkan pada sub stasiun IA ditemukan 6 jenis makrozoobenthos, IB ditemukan 3 jenis makrozoobenthos dan pada sub stasiun IC ditemukan 3 jenis makrozoobenthos. Sub stasiun IA dan IB dan IC kepadatan jenis Clypeomorus coralium berkisar antara 4,2- 5,4 ind $/ \mathrm{m}^{2}$. Sedangkan jenis yang makrozoobenthos yang paling sedikit ditemukan yaitu jenis Cassidula aurifelis, Nerita undata dan juga Terebralia sulcata.

Berdasarkan hasil pengamatan yang dilakukan pada stasiun II yang merupakan ekosistem mangrove dengan kategori rapat didapatkan hasil jumlah makrozoobenthos yang cukup banyak. Jenis Clypeomorus coralium memiliki nilai kepadatan tertinggi disetiap stasiun nya yaitu 2,6-4,2 ind $/ \mathrm{m}^{2}$. Sedangkan Geloena erosa, Casidula Aurifelis, Telescopium-telescopium serta nereis pelagica memiliki nilai kepadatan terendah. 
Tabel 5. Struktur Komunitas Makrozoobenthos

\begin{tabular}{cccccccc}
\hline No & Substasiun & H' $^{\prime}$ & Kriteria & E & Kriteria & C & Kriteria \\
\hline 1 & I A & 1,249 & Sedang & 0,731 & Tinggi & 0,405 & Rendah \\
2 & I B & 0,753 & Rendah & 0,599 & Sedang & 0,610 & Sedang \\
3 & I C & 0,532 & Rendah & 0,484 & Sedang & 0,725 & Sedang \\
\hline 4 & II A & 1,802 & Sedang & 0,866 & Tinggi & 0,202 & Rendah \\
5 & II B & 1,225 & Sedang & 0,719 & Tinggi & 0,413 & Rendah \\
6 & II C & 1,291 & Sedang & 0,865 & Tinggi & 0,309 & Rendah \\
\hline 7 & III A & 1,177 & Sedang & 0,642 & Tinggi & 0,200 & Rendah \\
8 & III B & 2,071 & Sedang & 0,900 & Tinggi & 0,146 & Rendah \\
9 & III C & 2,369 & Sedang & 0,953 & Tinggi & 0,103 & Rendah \\
\hline
\end{tabular}

Penelitian yang dilakukan pada 3 stasiun di Pulau Sepanjang menemukan beberapa spesies makrozoobenthos baik di ekosistem mangrove maupun lamun. Makrozoobenthos tersebut berasal dari filum Molusca, Echinodermata dan Arthropoda. Ketiga jenis filum ini mendiami ekosistem lamun di lokasi penelitian dengan komposisi filum Echinodermata lebih sering di jumpai dibandingkan filum Arthropoda dan Mollusca.

Perbedaan kepadatan berbagai jenis makrozoobenthos yang ditemukan di setiap stasiun penelitian dikarenakan perbedaan substrat, kondisi dan lokasi penelitian. Pada stasiun I ditemukan kepadatan yang lebih rendah di karenakan pada lokasi ini merupakan lokasi yang mengalami interaksi langsung dengan aktifitas manusia. Sedangkan pada stasiun III memiliki kepadatan makrozoobenthos yang lebih tinggi dibandingkan dengan lokasi lainnya dikarenakan pada lokasi tersebut merupakan daerah pesisir yang memiliki ekosistem lamun yang merupakan daerah terbuka sehingga jenis makrozoobenthos yang ditemukan lebih banyak di bandingkan lokasi penelitian yang berada pada Stasiun I dan Stasiun II yang merupakan ekosistem mangrove yang cenderung tertutup.

Tingginya jenis Clypeomorus coralium yang ditemukan pada stasiun I dan II dikarenakan jenis makrozoobenthos ini memiliki tingkat toleransi yang tinggi terhadap perubahan parameter kualitas perairan dan memiliki persebaran yang luas. Selain itu kondisi lingkungan atau keadaan ekosistem mangrove di lokasi tersebut mendukung dari pertumbuhan jenis makrozoobenthos jenis ini dengan kondisi mangrove yang mayoritas substrat dasarnya berupa lanau dengan serasah mangrove yang cukup tebal dan padat. Berdasarkan pola hidupnya jenis gastropoda umumnya herbivora. Hasil yang didapatkan dapat diketahui bahwa pada stasiun 1 memiliki nilai keanekaragaman rendah menandakan adanya produktivitas sangat rendah sebagai indikasi adanya tekanan yang berat dan ekosistem tidak stabil sehingga penyebaran tiap spesies rendah sehingga menyebabkan terjadinya dominasi suatu spesies.

Hasil analisa pada sub stasiun IIA-IIC yang berada pada stasiun 2 diketahui memiliki Indeks Keanekaragaman sedang, Indeks Keseragaman tinggi dan nilai Indeks Dominasi rendah. Hasil analisa Indeks Keanekaragaman pada sub stasiun III A- IIIC 3 didapatkan Indeks Keanekaragaman sedang, Indeks Keseragaman tinggi dan Indeks Dominasi rendah. Indeks Keanekaragaman yang didapatkan menandakan pada stasiun 2 dan 3 produktivitas lingkungan cukup, kondisi ekosistem cukup seimbang, tekanan ekologis sedang, penyebaran tiap spesies sedang dan kestabilan komunitas sedang sehingga tidak terjadinya dominasi dari suatu spesies. Perbedaan nilai struktur komunitas makrozoobenthos di setiap lokasi terutama pada stasiun I dan II terutama pada setiap substasiun nya dikarenakan jumlah jenis makrozoobenthos yang ditemukan di setiap sub stasiun memiliki jumlah yang berbedabeda. Perbedaan ini dikarenakan kondisi lokasi tersebut berbeda terutama dalam segi substrat dasar. Pada sub stasiun IA dan IIA substrat pada lokasi tersebut cenderung lunak, sedangkan pada substasiun IB - IC dan IIB - IIC substrat dasar cenderung padat dan tersusun oleh serasah mangrove yang cukup tebal. Akibatnya makrozoobenthos yang ditemukan cenderung memperoleh hasil yang lebih sedikit. Selain itu faktor perpindahan atau migrasi dari makrozoobenthos yang ditemukan di setiap lokasi menjadi faktor yang menyebabkan 
adanya perbedaan struktur komunitas makrozoobenthos disetiap lokasi yang dijadikan lokasi penelitian.

\section{KESIMPULAN}

Kesimpulan yang didapatkan dari penelitian sebagai berikut.

a. Berdasarkan hasil penelitian yang telah dilakkukann di setiap substasiun yang berada di pulau sepanjang kualitas perairan di pulau sepanjang masih sesuai bagi kehidupan makrozoobenthos yang mendiami lokasi tersebut hannya saja terdapat penemaran antropogenik yang terjadi diwalayah tersebut yang bersumber dari aktifitas manusia dan kotoran hewan yang ditandai dengan tingginya nitrat dan fosfat yang ada dilokasi tersebut.

b. Komposisi makrozoobenthos di perairan pulau sepanjang pada setiap lokasi penelitian berbeda beda. Pada stasiun satu dan dua ditemukan 3 filum makrozoobenthos yang mendiami wilayah tersebut. Stasiun 1 dan 2 jenis Cylypemorus coralium lebih sering dijumpai. Stasiun 3 jenis Cheritium zonatum, Nerita albicila, dan Cyprea anulus lebih sering dijumpai. Filum Mollusca mempnyai jumlah lebih banyak di bandingkan filum Annelida, Arthropoda dan Echinodermata di setiap lokasi.

c. Stasiun 1 memiliki nilai keanekaragaman yang rendah dan menandakan adanya produktivitas sangat rendah sebagai indikasi adanya tekanan yang berat dan ekosistem tidak stabil sehingga penyebaran tiap spesies rendah dan kestabilan komunitas rendah dan menyebabkan terjadinya dominasi suatu spesies.

d. Stasiun 2 dan 3 memiliki nilai keanekaragaman sedang menandakan Keanekaragaman sedang, produktivitas cukup, kondisi ekosistem cukup seimbang, tekanan ekologis sedang penyebaran tiap spesies sedang dan kestabilan komunitas sedang sehingga tidak terjadinya dominasi dari suatu spesies.

\section{DAFTAR PUSTAKA}

Bengen, D. G. 2003. Pedoman teknis: Pengenalan dan pengelolaan ekosistem mangrove. PKSPL-IPB. Bogor.

Dahuri R. 2003. Keanekaragaman Hayati Laut :Aset Pembangunan Berkelanjutan Indonesia. PT Gramedia Pustaka Utama.

Dahuri R, 2003. Paradigma Baru Pembangunan Indonesia Berbasis Kelautan, Orasi IImiah: Guru besar Tetap Bidang Pengelolaan Sumberdaya pesisir dan Laut Fakultas Perikanan dan Ilmu Kelautan Institut Pertanian Bogor.

Krebs, C. J.1989. Ecological Methodology. Harper Collins Publisher, New York.

Setiawan D. 2010. Studi Komunitas Makrozoobentos Di Perairan Sungai Musi Sekitar Kawasan Industri Bagian Hilir Kota Palembang. Prosiding Seminar Nasional Limnologi. 5: 217-228.

Chessman B. 1995. "Rapid Assessment of River Using Macroinvertebrates: a Procedure based on Habitat Specific Sampling, Family Level Identification and Abiotic Index". Australian Journal of Ecology. 20(1): 122129.

Pong-Masak.P.R \& Pirzan.A.M 2006. Komunitas Makrozoobentos pada Kawasan Budidaya Tambak di Pesisir Malakosa Parigi-Moutong, Sulawesi Tengah. Biodiversitas. 7(4). 354-360. ISSN: 1412-033X. 